\title{
Effect of Addition of Tiger Grouper (Epinephelus fuscoguttatus) Skin Collagen to Cork Fish (Channa striata) Albumin Ointment on Closure of Cuts
}

\author{
Hansen Gunawan*, Eddy Suprayitno** \\ *Department of Fisheries Technology \\ Faculty of Fisheries and marine science \\ Brawijaya university Indonesia \\ hansengun_27@student.ub.ac.id \\ **Department of Fisheries Technology \\ Faculty of Fisheries and marine science \\ Brawijaya university Indonesia \\ eddysuprayitno@ub.ac.id \\ DOI: 10.29322/IJSRP.11.07.2021.p11536 \\ http://dx.doi.org/10.29322/IJSRP.11.07.2021.p11536
}

\begin{abstract}
Ointments are semisolid preparations intended for topical application to the skin or mucous membranes. The ointment formulation requires the presence of an ointment base, the ointment base itself is an inactive carrier substance from topical preparations that can be in the form of liquid or solid which brings the active ingredient to contact with the skin. The ointment base used in an ointment formulation must be inert in other words not to damage or reduce the therapeutic effect of the drug it contains. The results of the first study showed that differences in collagen concentrations affected the quality of albumin ointment, namely $\mathrm{pH}$, viscosity, protein content, fat content, and water content. The best albumin ointment was obtained at $0.8 \%$ collagen concentration with the following results pH 6.8, viscosity $27980 \mathrm{cP}$, protein content $1.34 \%$, fat content $88.29 \%$, and water content $2.24 \%$. The results of the amino acid profile test showed that the highest result was Glycine $5618.18 \mathrm{mg} / \mathrm{kg}$ and the lowest was L-Tyrosine $<66.93 \mathrm{mg} / \mathrm{kg}$. Then continued in the second study, namely amino acid profile testing, zinc levels and experimental mice, the results of observations on day 3 , day 5 , and day 7 showed that the best concentration of albumin ointment treatment underwent a wound closure process. $75 \%$ on the 7 th day.
\end{abstract}

Index Terms- ointment, collagen, wound closure, amino acids

\section{INTRODUCTION}

Wound healing components consist of albumin, omega 3, omega 6 and collagen. It is necessary to apply these wound healing components to accelerate wound closure (Nicodemus et al., 2014). Albumin is abundant in snakehead fish. According to Firlianty and Pratasik (2018), albumin is a globular protein that is often applied clinically for nutritional improvement, the formation of new body tissues and accelerating the healing of body tissues, for example after surgery, burns and when sick. Omega-3 fatty acids and omega- 6 fatty acids also play a role in the wound healing process (Andrie and Sihombing, 2017). Omega-3 fatty acids, especially EPA (eicosapentaenoic acid) have been shown to help fibroblasts synthesize collagen. In addition, EPA also plays a role in increasing the number of cytokines of the IL-6 type, where with the increase in IL-6 there is an increase in collagen production by fibroblasts. With the increase in the amount of collagen, the wound healing process will also take place quickly. While omega- 6 fatty acids, especially arachidonic acid, are the main substrates for the synthesis of eicosanoids which have pro and anti-inflammatory effects so that they can accelerate the inflammatory phase. (Daisa, et al., 2017). Collagen is one of the main connective tissues of animal protein and has been widely used as a biomedical material. Collagen is the most abundant protein in animal tissues with a proportion of $30 \%$ of the total body protein as the main component of connective tissue, muscle, gums and skin (Ata, et al., 2016). Collagen according to Aisyah, et al., (2017) plays a vital role in the wound healing process in connective tissue. Macrophages in the wound release FGF (Fibroblast Growth Factor) and TGF- $\beta$ (Transforming Growth Factor- $\beta$ ) thereby stimulating fibroblast proliferation and producing collagen. Collagen serves to maintain moisture in the wound. A moist environment is needed to accelerate the wound healing process by increasing reepithelialization and stimulating the proliferation and migration of epithelial cells, increasing the activity of growth factors that maintain adequate surface oxygen and maintain nutrient transport. The source of collagen for the manufacture of ointments is grouper skin. According to Suprayitno (2020), grouper skin is known to have the highest collagen content compared to other fish. Collagen plays an important role in the formation of tissues and organs, is involved in various biological functions of cells such as cell division, defense, and differentiation (Imamah, 2015). 
Albumin extracted from snakehead fish, linseed oil as a source of omega 3, omega 6 fatty acids from black cumin seed oil and collagen from grouper skin were added to the ointment making process to speed up the wound closure process. This study aims to determine the effect of adding collagen from grouper skin to the ointment in the process of wound closure.

\section{MATERIALS AND METHODS}

\subsection{Material}

The ingredients used to make albumin ointment are grouper skin collagen, albumin extract, flaxseed oil as a source of omega 3 , and black cumin seed oil as a source of omega 6 . The ingredients for making collagen are grouper skin, $\mathrm{NaOH}$, acetic acid, $\mathrm{NaCl}$, membrane dialysis, and aquades. Supporting materials for the manufacture of ointments are fillers in the form of adeps lanae and vaseline flavum. The materials used for the analysis include potassium sulfate (K2SO4), $\mathrm{NaCl}, \mathrm{H} 2 \mathrm{SO} 4,3 \%$ boric acid, $0.02 \mathrm{~N} \mathrm{HCl}, \mathrm{hexane}$, spirtus, aquades, physiological solutions and cotton. The material used for animal testing is mice.

This research method is an experimental method. The first study aimed to obtain the optimal concentration of collagen added to the manufacture of albumin ointment in order to obtain the best quality ointment for the second study. While the second stage of the study aimed to see the process of wound closure in experimental animals using albumin ointment with the best quality compared to negative controls and negative controls.

\subsubsection{Albumin Extract Making}

Albumin production begins with the preparation of raw materials in the form of snakehead fish. First, the snakehead fish is turned off and filleted to take the fish meat which is then cut to a size of $5 \times 5 \mathrm{~cm}$. Then prepare a steamer filled with water and heated to a temperature of $70 \mathrm{C}$. Then place a basin that has been given a filter on top. Then enter the cork fish meat as much as 250 grams and steamed for 30 minutes. Obtained albumin extract in the basin.

\subsubsection{Collagen Making}

The manufacture of collagen begins with the preparation of raw materials by cutting a sample measuring $1 \mathrm{x} 1 \mathrm{~cm}$. Then soaked in $0.1 \mathrm{M} \mathrm{NAOH}$ for 24 hours with a ratio of 1:20 (w/v). After 24 hours the sample was washed using distilled water until the $\mathrm{pH}$ of the sample was close to 7 . Then the sample was extracted in $0.5 \mathrm{M}(1: 10 \mathrm{w} / \mathrm{v})$ acetic acid solution for 24 hours. The extraction result was filtered to separate the residue and supernatant. The supernatant was precipitated for 24 hours by adding $\mathrm{NaCl}$ to a solution concentration of $0.9 \mathrm{~mol} \mathrm{dm}$. The precipitate was then centrifuged at $3500 \mathrm{rpm}$ for 20 minutes. The centrifuged collagen was dissolved in $0.5 \mathrm{M}$ acetic acid $(1: 10 \mathrm{w} / \mathrm{v})$ and then inserted into the dialysis membrane. The dialysis membrane containing collagen was then immersed in $0.1 \mathrm{M}$ acetic acid solution which was changed every 3 hours. After 6 hours the membrane containing collagen was immersed in distilled water which was changed every 3 hours until the $\mathrm{pH}$ of the distilled water used was 5 .

\subsubsection{Albumin Ointment Production}

The preparation of the ointment begins with adding BHT in the first mortar, then adding the oil phase from snakehead fish extract and grinding until the BHT dissolves. Add a little adeps lanae and stir until homogeneous. Next, dissolve methyl paraben and propyl paraben in propylene glycol in a beaker glass, then add the water phase from the snakehead fish extract, stir until homogeneous. In the second mortar, the remaining adeps lanae was added, little by little the mixture of methyl paraben, propyl paraben, and the water phase of snakehead fish extract was added while stirring until homogeneous. Then mix the ingredients for the first mortar and the second mortar, add vaseline flavum, grind until homogeneous. The preparation is put into an ointment pot (Andrie and Sihombing, 2017). The addition of grouper skin collagen, linseed oil and black cumin oil was carried out when mixing the first and second mortar. 


\section{RESULT AND DISCUSSION}

\section{$3.1 \mathrm{pH}$}

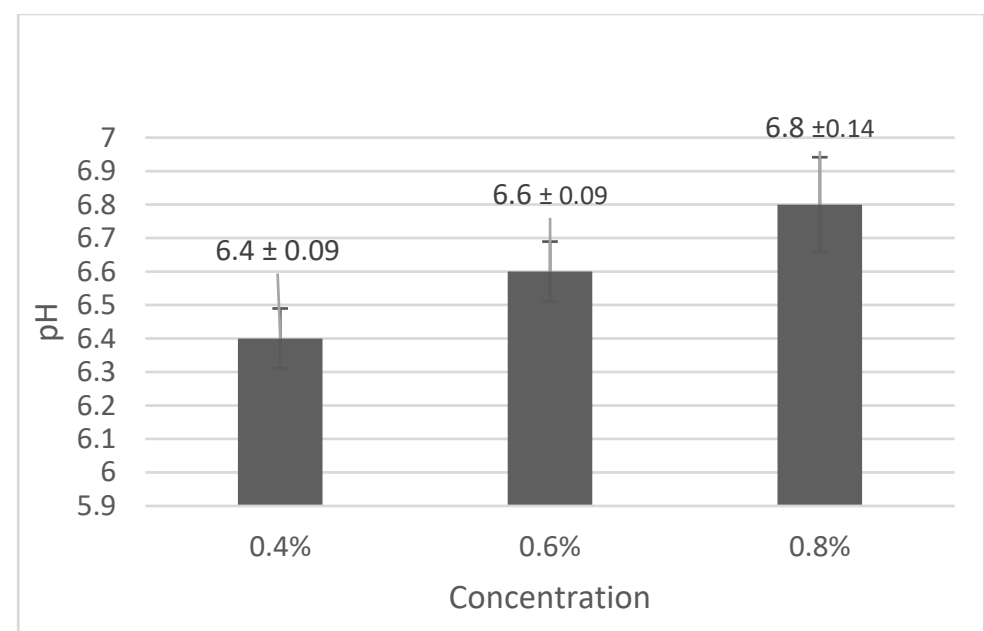

Figure 1. The Result of $\mathrm{pH}$

The $\mathrm{pH}$ of albumin ointment with different concentrations of collagen resulted in different $\mathrm{pH}$ values. At $0.4 \%$ collagen concentration the $\mathrm{pH}$ value was $6.4,0.6 \%$ concentration was 6.6 , and $0.8 \%$ concentration was $6.8 \mathrm{pH}$. The highest pH value was obtained from the concentration of collagen extract, namely $0.8 \%$ with a $\mathrm{pH}$ value of 6.8 , and the lowest was obtained at $0.4 \%$ collagen concentration of 6.4. The highest and lowest $\mathrm{pH}$ values are still within the safe $\mathrm{pH}$ range of the ointment, which is between 4.5-7.0. Ointments should have a $\mathrm{pH}$ that is approximately the same as the $\mathrm{pH}$ of the skin so that it is not easy to irritate the skin (Latifah et al., 2016).

\subsection{Viscosity}

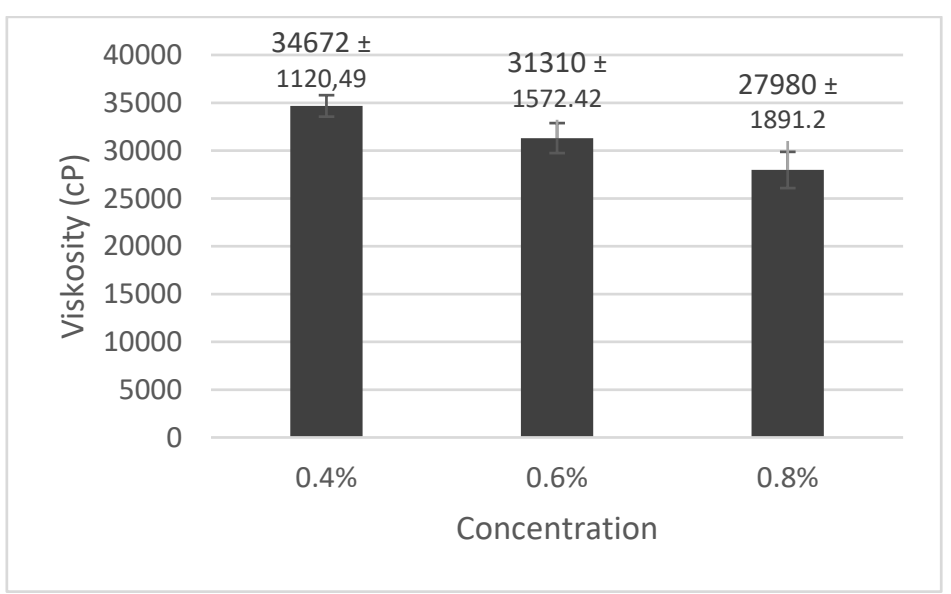

Figure 2. The Result of Viscosity

The viscosity value of albumin ointment at a collagen concentration of $0.4 \%$ was $34672 \mathrm{cP}$, a concentration of $0.6 \%$ obtained a viscosity value of $31310 \mathrm{cP}$, and at a concentration of $0.8 \%$ it was $27980 \mathrm{cP}$. The result of the viscosity of the ointment that has the highest value is albumin ointment with a collagen concentration of $0.4 \%$ at $34672 \mathrm{cP}$, and the lowest result is obtained at a concentration of $0.8 \%$ at $27980 \mathrm{cP}$. The viscosity value of albumin ointment produced is still in the range of good ointment viscosity. The value of the viscosity range of the ointment is in the range of viscosity values of 2,000-50,000 cP (Lilyswati and sagala, 2019). 


\subsection{Protein Content}

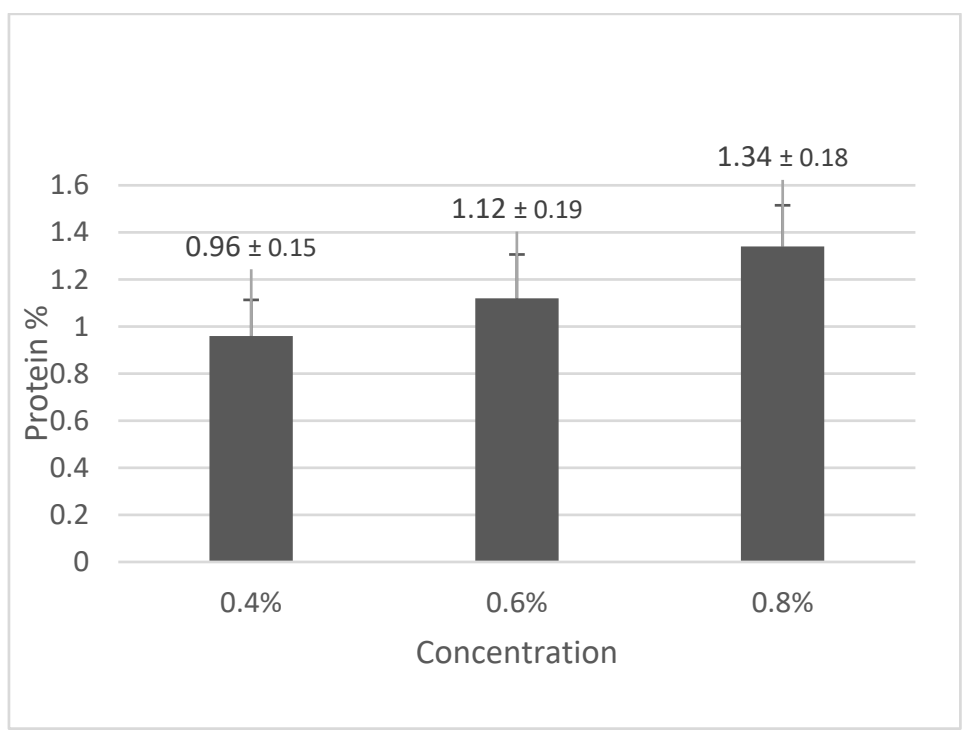

Figure 3. The Result of Protein Content

The protein content of albumin ointment at a collagen concentration of $0.4 \%$ was $0.96 \%$, a concentration of $0.6 \%$ obtained a protein content of $1.12 \%$, and a concentration of $0.8 \%$ was $1.34 \%$. The protein content of albumin ointment which has the highest value is $0.8 \%$ collagen concentration of $1.34 \%$, and the lowest result is $0.4 \%$ concentration of $0.96 \%$. The protein content of the albumin ointment produced was lower when compared to the protein content of the ointment in the study of Momoh, et al., (2013), which was $8.5 \%$. The value of protein content in albumin ointment increased along with the increase in collagen concentration. It can be concluded that the higher the collagen concentration, the greater the protein content produced.

\subsection{Fat Content}

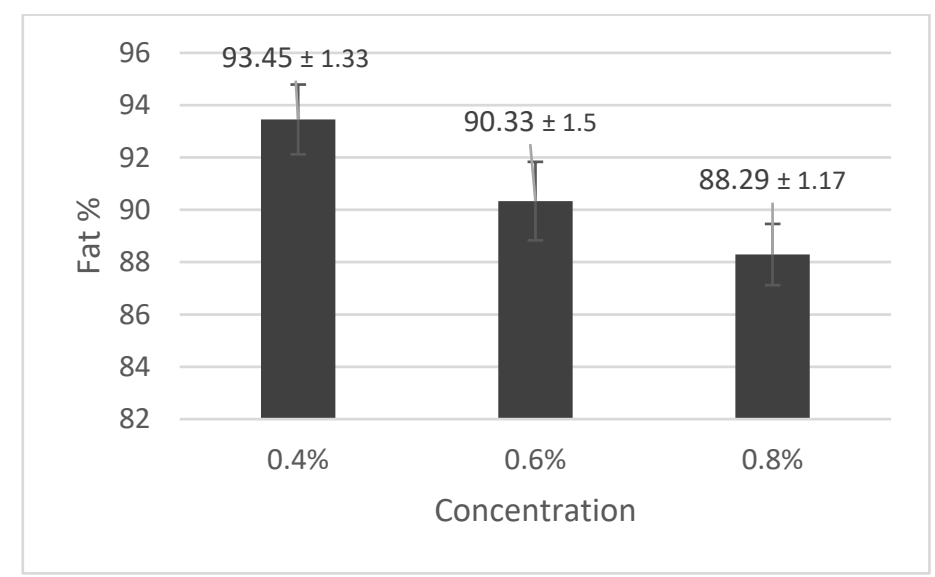

Figure 4. The Result of Fat Content

The fat content of albumin ointment at a collagen concentration of $0.4 \%$ was $93.45 \%$, a concentration of $0.6 \%$ obtained a fat content of $90.33 \%$, and at a concentration of $0.8 \%$ it was $88.29 \%$. The fat content of albumin ointment which has the highest value is $0.4 \%$ collagen concentration of $93.45 \%$, and the lowest result is $0.8 \%$ concentration of $88.29 \%$. The fat content of the albumin ointment produced was higher when compared to the fat content of the ointment in the study of Momoh, et al., (2013), amounting to 13.4\%. 


\subsection{Water Content}

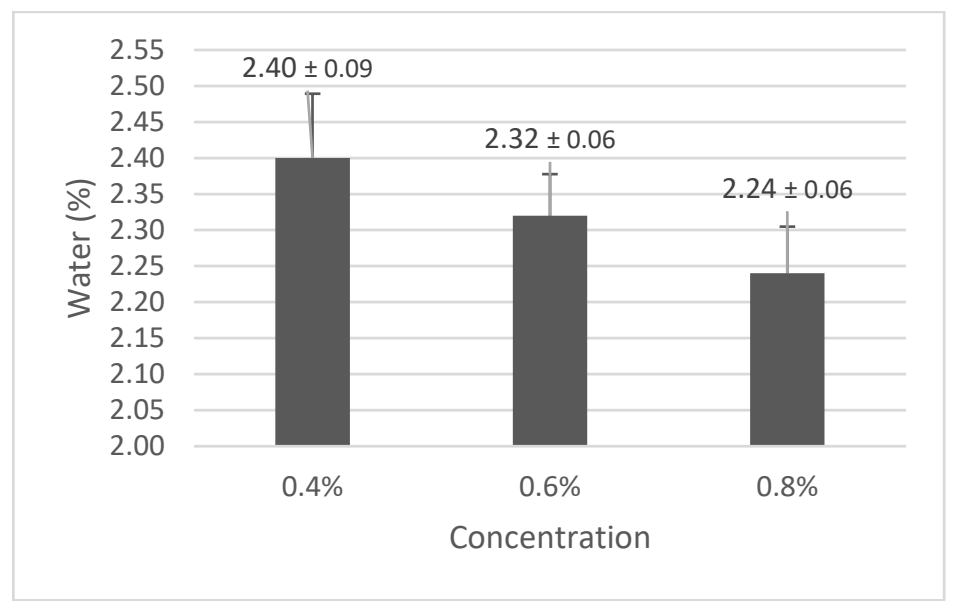

Figure 5. The Result of Water Content

The water content of albumin ointment at $0.4 \%$ collagen concentration is $2.40 \%, 0.6 \%$ concentration is $2.32 \%$ water content, and $0.8 \%$ concentration is $2.24 \%$. The water content of albumin ointment which has the highest value is $0.4 \%$ collagen concentration of $2.40 \%$, and the lowest result is $0.8 \%$ concentration of $2.24 \%$. The water content of the albumin ointment produced was lower than the water content of the ointment in the study of Chen, et al., (2018), which was 19.1\%. According to Pratama, et al., (2014), the water content is influenced by the water content of the added material.

\subsection{Organoleptic}

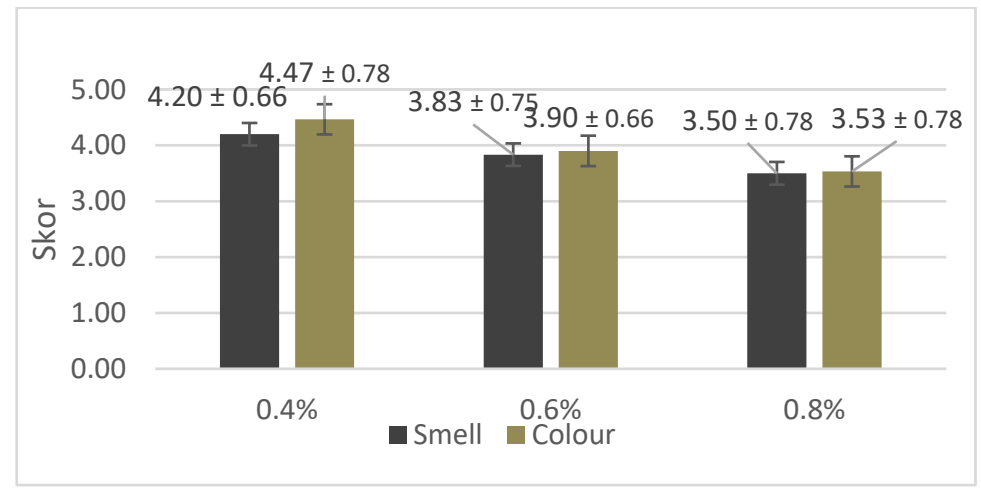

Figure 6. The result of Organoleptic

Organoleptic assessment of albumin ointment with different collagen concentrations showed differences. In the treatment of collagen extract concentration of $0.4 \%$ the color parameter showed a value of 4.47 , at a concentration of $0.6 \%$ it was 3.90 , and at a concentration of $0.8 \%$ it showed a value of 3.53 . While the treatment of different collagen concentrations on the aroma parameter showed different values. The aroma value of $0.4 \%$ concentration is $4.20,0.6 \%$ concentration is 3.83 , and at $0.8 \%$ concentration indicates a value of 3.50. In organoleptic assessment of albumin ointment with different collagen concentrations, the lowest value for color parameters was found at $0.8 \%$ collagen concentration of 3.53 and the highest value was $0.6 \%$ collagen concentration of 4.47 . For the aroma parameter, the lowest value was found at a collagen concentration of $0.8 \%$ at 3.50 and the highest value was found at a collagen concentration of $0.6 \%$ at 4.20 . The lower the value of the organoleptic test results indicate that the panelists do not like the aroma and color of the albumin ointment and conversely, the higher the organoleptic test results indicate that the panelists like the aroma and color of the albumin ointment.

\subsection{Experimental Animal Testing}

After knowing the optimal collagen concentration for making the best quality albumin ointment, namely a concentration of $0.8 \%$ which was then tested on experimental animals to determine the effect of albumin ointment on wound closure, further tests were analysis of amino acid profile of albumin ointment, and zinc level test. Albumin ointment with the best concentration of $0.8 \%$ was then compared with negative control and positive control. Mice were injured with a wound length of $2 \mathrm{~cm}$. The wound closure process was measured for 7 days with observations on the 3rd day, 5th day and 7th day. 


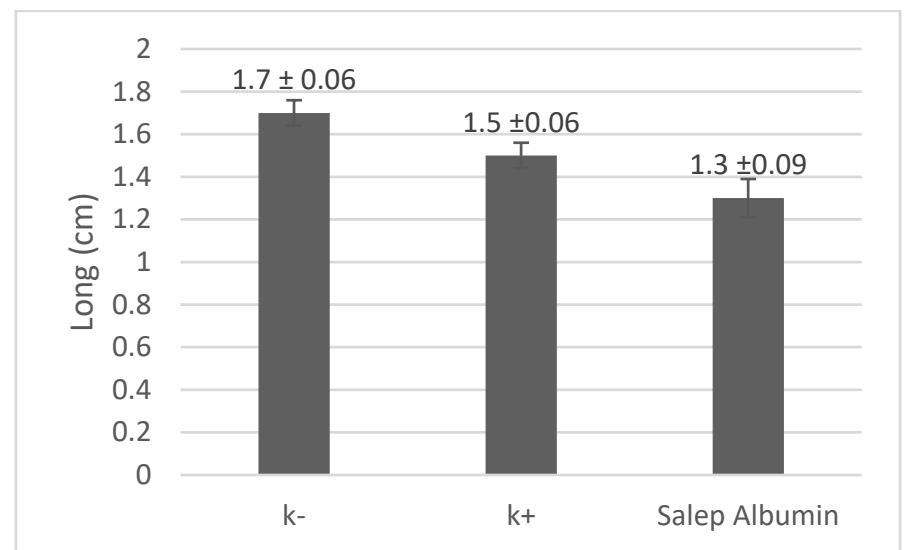

Figure 7. The Result of Day 3

On the 3rd day different treatments gave different results on the wound closure process. The negative control treatment showed an average wound length of $1.7 \mathrm{~cm}$, the positive control treatment was $1.5 \mathrm{~cm}$, and the albumin ointment treatment was $1.3 \mathrm{~cm}$. The best wound closure on day 3 was obtained by albumin ointment treatment with a wound length of $1.3 \mathrm{~cm}$, while the longest wound closure was in the negative control treatment of $1.7 \mathrm{~cm}$. The wound closure process on the best treatment on the 3rd day was $35 \%$ which was then compared with the study of Nicodemus, et al., (2014), wound closure using toman fish extract on the third day was $25.93 \%$.

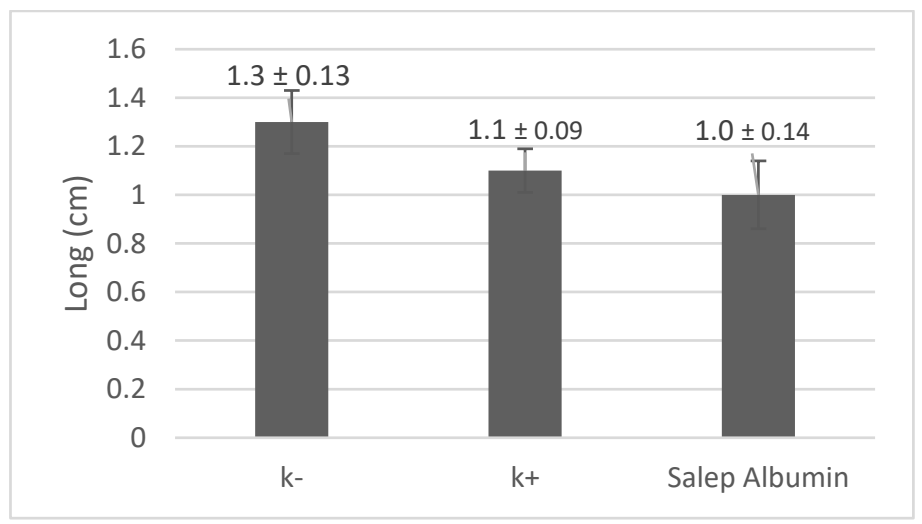

Figure 8. The Result of Day 5

On day 5, different treatments gave different results on the wound closure process. The negative control treatment showed an average wound length of $1.3 \mathrm{~cm}$, the positive control treatment was $1.1 \mathrm{~cm}$, and the albumin ointment treatment was $1.0 \mathrm{~cm}$. The best wound closure on day 5 was obtained by albumin ointment treatment with a wound length of $1.0 \mathrm{~cm}$, while the longest wound closure was in the negative control treatment of $1.3 \mathrm{~cm}$. The process of wound closure on the best treatment on the 5 th day was $50 \%$ which was then compared with the study of Nicodemus, et al., (2014), wound closure using toman fish extract on the fifth day was $63.46 \%$.

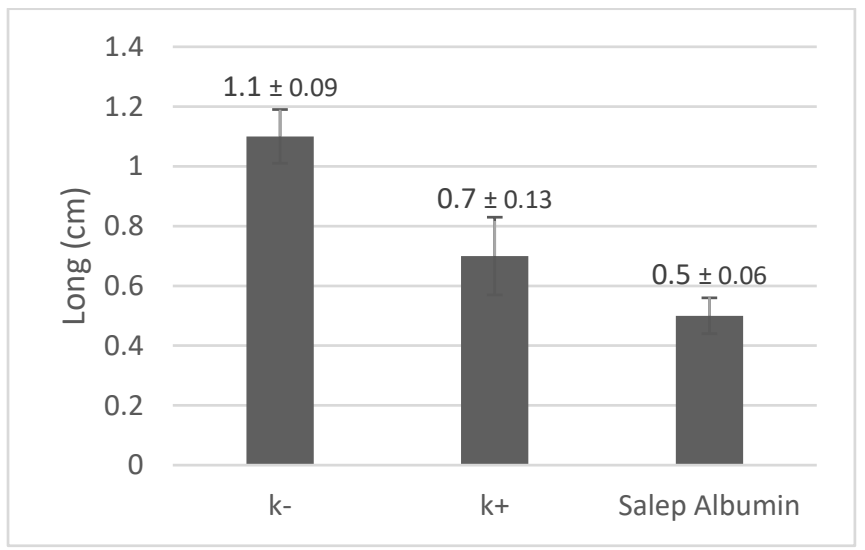

Figure 9. The Result of Day 7 
On the 7th day, different treatments gave different results to the wound closure process. The negative control treatment showed an average wound length of $1.1 \mathrm{~cm}$, the positive control treatment was $0.7 \mathrm{~cm}$, and the albumin ointment treatment was $0.5 \mathrm{~cm}$. The best wound closure on day 7 was obtained by albumin ointment treatment with a wound length of $0.5 \mathrm{~cm}$, while the longest wound closure was in the negative control treatment of $1.1 \mathrm{~cm}$. The process of wound closure on the best treatment on the 7th day was $75 \%$ which was then compared with the study of Nicodemus, et al., (2014), wound closure using toman fish extract on the seventh day was $63.46 \%$.

\subsection{Amino Acid Profile}

\begin{tabular}{clcc}
\hline No & Parameter & Unit & Result \\
\hline 1 & L-Histidine & $\mathrm{mg} / \mathrm{kg}$ & 7962,39 \\
2 & L-theonine & $\mathrm{mg} / \mathrm{kg}$ & 32106,07 \\
3 & L-Proline & $\mathrm{mg} / \mathrm{kg}$ & 122104,55 \\
4 & L-Tyrosine & $\mathrm{mg} / \mathrm{kg}$ & 4440,89 \\
5 & L-Leucine & $\mathrm{mg} / \mathrm{kg}$ & 27718,28 \\
6 & L-Aspartic Acid & $\mathrm{mg} / \mathrm{kg}$ & 41204,48 \\
7 & L-Lysine & $\mathrm{mg} / \mathrm{kg}$ & 29096,02 \\
8 & Glycine & $\mathrm{mg} / \mathrm{kg}$ & 255328,48 \\
9 & L-Arginine & $\mathrm{mg} / \mathrm{kg}$ & 94073,31 \\
10 & L-Alanine & $\mathrm{mg} / \mathrm{kg}$ & 80295,46 \\
11 & L-Valin & $\mathrm{mg} / \mathrm{kg}$ & 23586,58 \\
12 & L-Isoleucine & $\mathrm{mg} / \mathrm{kg}$ & 14205,62 \\
13 & L-Phenylalanine & $\mathrm{mg} / \mathrm{kg}$ & 23833,40 \\
14 & L-Glutamic Acid & $\mathrm{mg} / \mathrm{kg}$ & 81460,82 \\
15 & L-Serine & $\mathrm{mg} / \mathrm{kg}$ & 39327,16 \\
\hline
\end{tabular}

The highest amino acid content was Glycine at $255328.48 \mathrm{mg} / \mathrm{kg}$ and the lowest was L-Tyrosine at $4440.89 \mathrm{mg} / \mathrm{kg}$. Collagen is then used as the active substance of albumin ointment. The amino acid profile of albumin ointment is as follows.

\begin{tabular}{clcc}
\hline No & Parameter & Unit & Result \\
\hline 1 & L-Histidine & $\mathrm{mg} / \mathrm{kg}$ & 213,63 \\
2 & L-theonine & $\mathrm{mg} / \mathrm{kg}$ & 694,60 \\
3 & L-Proline & $\mathrm{mg} / \mathrm{kg}$ & 2856,98 \\
4 & L-Tyrosine & $\mathrm{mg} / \mathrm{kg}$ & $<66,93$ \\
5 & L-Leucine & $\mathrm{mg} / \mathrm{kg}$ & 646,72 \\
6 & L-Aspartic Acid & $\mathrm{mg} / \mathrm{kg}$ & 1151,28 \\
7 & L-Lysine & $\mathrm{mg} / \mathrm{kg}$ & 798,88 \\
8 & Glycine & $\mathrm{mg} / \mathrm{kg}$ & 5618,18 \\
9 & L-Arginine & $\mathrm{mg} / \mathrm{kg}$ & 2028,63 \\
10 & L-Alanine & $\mathrm{mg} / \mathrm{kg}$ & 1973,85 \\
11 & L-Valin & $\mathrm{mg} / \mathrm{kg}$ & 531,62 \\
12 & L-Isoleucine & $\mathrm{mg} / \mathrm{kg}$ & 324,11 \\
13 & L-Phenylalanine & $\mathrm{mg} / \mathrm{kg}$ & 448,1 \\
14 & L-Glutamic Acid & $\mathrm{mg} / \mathrm{kg}$ & 2083,17 \\
15 & L-Serine & $\mathrm{mg} / \mathrm{kg}$ & 981,06 \\
\hline
\end{tabular}

The highest essential amino acid content was Glycine at $5618.18 \mathrm{mg} / \mathrm{kg}$ and the lowest was L-Tyrosine at $<66.93 \mathrm{mg} / \mathrm{kg}$. The highest amino acid in collagen is glycine. According to Alhana, et al., (2015), the basic molecule of collagen is formed from three polypeptide chains that are twisted together to form a triple helix structure with a typical amino acid arrangement, namely Gly-X-Y, at position $\mathrm{X}$ is proline and position $\mathrm{Y}$ is hydroxyproline. Glycine amino acid is found in every third position of the collagen triple helix (Gly-X-Y) amino acid arrangement, where 35\% of the amino acids that make up the collagen triple helix are proline and hydroxyproline.

\subsection{Zinc Content}

The best concentration of $\mathrm{Zn}$ in albumin ointment was $2.46 \mathrm{mg} / 100 \mathrm{~g}$. The content of $\mathrm{Zn}$ increases and accelerates the wound healing process. This can happen because $\mathrm{Zn}$ plays an important role in protein synthesis and cell multiplication. Albumin and $\mathrm{Zn}$ This publication is licensed under Creative Commons Attribution CC BY. 
together play an important role in wound healing because albumin has the ability to bind $\mathrm{Zn}$ and transport it in blood plasma (Puspitasari and Suprayitno, 2020).

\section{CONCLUSION}

The conclusions obtained from this study are as follows:

Collagen extract concentration of $0.8 \%$ is the optimal concentration to produce the best albumin ointment. It includes a $\mathrm{pH}$ value of 6.8, a viscosity value of $27980 \mathrm{cP}$, a protein content of 1.34 , a fat content of 99.39 , and a water content of 2.24 .

The results showed that giving different treatments to wounds had a significant effect on the wound closure process. On the 3rd day, 5th day, and 7th day observation, the best wound closure process was $75 \%$ in experimental animals treated with albumin ointment on the 7th day.

\section{REFERENCES}

Aisyah, Z. Mufarikoh, and A. Andini. 2017. Pengaruh pemberian topical ekstrak kolagen kulit ikan lele sangkuriang (Clarias gariepinus) terhadap TNF-A dan jumlah fibroblast pada luka bakar derajat dua tikus wistar. Medical and Health Science Journal. 1(1): 9-13. ISSN: 2549-7588.

Alhana, P. Suptijah, and K. Tarman. 2015. Ekstaksi dan karakterisasi kolagen dari daging teripang gamma. JPHPI. 18(2): $150-161$. ISSN: 2303-2111.

Andrie, M., and D. Sihombing. 2017. Efektivitas sediaan salep yang mengandung ekstrak ikan gabus (Channa striata) pada proses penyembuhan luka akut stadium II terbuka pada tikus jantan galur wistar. Pharm Sci Res. ISSN: 2407-2354.

Ata, S. T., R. Yulianty, F. J. Sami, and N. Ramli. 2016. Isolasi kolagen dari kulit dan tulang ikan cakalang (Katsuwonus pelamis). Journal of Pharmaceutical and Medicinal Sciences. 1(1): 27-30. ISSN: 2580-3281.

Chen, X. M., Z. H. Li, S. H. Tao. Y. F. Chen, Z. H. Chen, L. B. Guo. 2018. Effect of FPZ, a total flavonoids ointment topical applications from pouzolzia zeylanica var. microphlla, on mice skin infections. Brazilian Journal of Pharmaconosy. 1-6: ISSN: 0102-6952.

Daisa, F., M. Andrie, and W. Taurina. 2017. The effectiveness test of oil phase ointment containing snakehead fish (Channa striata) extract on open stage ii acute wounded wistar strain male rats. Trad Med. J. 22(2): 97-102. ISSN: 1410-5918.

Firlianty and S. B. Pratasik. 2018. Potensi pudding ikan toman (Channa micropeltes) dan ikan gabus (Channa striata) untuk percepatan penyembuhan pada hewan uji tikus. Jurnal Agribisnis Perikanan. 11(2): 65-69. ISSN: 2598-8298.

Imamah. I. N. 2015. Pengaruh pemberian kolagen ikan terhadap proses penyembuhan luka insisi (studi eksperimen pada tikus putih Rattus norvegicus). Jurnal Husada Mahakam. 4(1): 1-71. ISSN: 1978-3833.

Latifah, F., N. Sugihartini, and T. Yuwono. 2016. Evaluation of physical properties and irritation index of lotion containing syzigium arimaticum clove essential oil at various concentration. Trad. Med. J. 21(1): 1-5. ISSN: 1410-5918.

Lilyswati and Z. Sagala. 2019. Formulasi salep ekstrak daun pare (Momordica charantia L.) dan uji aktivitas terhadap bakteri staphylococcus aureus. Indonesia Natural Research Pharmaceutical Journal. 3(2): 33-43. ISSN: 2502-8421.

Momoh, M. A., S. A. Brown, and C.C. Muogbo. 2013. Formulation and evaluation of cat fish slim mucin ointment for wound healing. Tropical Journal of Pharmaceutical Research December. 12(6): 885-890. ISSN: 1596-5996.

Nicodemus, M. Andrie, and S. Luliana. 2014. Uji efek penyembuhan luka sayat ekstrak ikan toman (Channa micropeltes) secara oral pada tikus putih jantan wistar. Jurnal Mahasiswa Farmasi. 1(1):1-14.

Pratama, R. I., I. Rostini, and E. Liviawaty. 2014. Karakteristik biscuit dengan penambahan tepung tulang ikan jangilus (Istiophorus Sp). Jurnal Akuatika. 5(1): 30-39. ISSN: 0853-2532.

Puspitasari, D. and E. Suprayitno. 2020. The effect of giving fish cork albumin gel (channa striata) to the mice wound closure. International Journal of Scientific and Research Publications. 10(7). ISSN: 2250-3153.

This publication is licensed under Creative Commons Attribution CC BY. 
Suprayitno, E. 2020. Profiles of omega 6 fatty acids of black cumin oil in the cork-based albumin ointment for woundd closure.

RJOAS. 11(107). ISSN: 2226-1184 